\title{
THE SO-CALLED SERIES-QUALIFIER CANON
}

\author{
Adam G. Crews
}

\begin{abstract}
In Facebook, Inc. v. Duguid, a near-unanimous Supreme Court forcefully applied the so-called series-qualifier canon, which posits (among other things) how postpositive modifiers normally attach to certain antecedents. With this canon, the Court identified a presumptive natural reading of the statute at issue, and that presumption framed the rest of the Court's analysis. Concurring only in the judgment, Justice Alito agreed with the Court's interpretation but expressed concern over the majority's heavy reliance on the canon. In Justice Alito's view, the majority used the canon too much like a rule, despite intuitive reasons to doubt its force.

Justice Alito's intuitions were exactly right. The so-called seriesqualifier canon is an unjustified revision to a principle from a single case in the $1920 \mathrm{~s}$ - a case that itself materially distorted the real series-qualifier principle that America borrowed from England. This Essay tells that story. Drawing on formal linguistics and interpretive history, I explain that a seriesqualifier principle initially served a much smaller role than the contemporary series-qualifier canon, a supposed "rule" that does not necessarily describe ordinary English usage or processing. By relying on this contemporary misstatement and not on the true series-qualifier principle, the Court in Facebook committed a serious process error and potentially set up lower courts to approach interpretation in a way that will undermine textualism's core commitments and goals.
\end{abstract}

AUTHOR-Appellate Counsel, Federal Communications Commission. Thanks to the Northwestern University Law Review Online staff for excellent work on this Essay, which I dedicate to the memory of Dr. Patricia S. Burton, $\mathrm{Ph} . \mathrm{D}$. All views are my own and do not necessarily represent the views of the United States, my agency employer, or any individual FCC commissioner. 


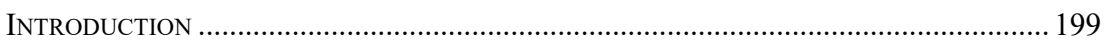

I. Modern TextUAList Commitments ...................................................................... 202

A. Textualism in Action at the Supreme Court................................................. 202

B. Canons and the Risk of Over-Formalization ..............................................2 204

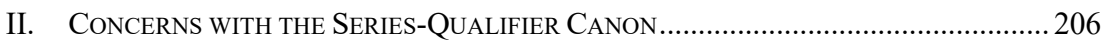

A. Understanding the Series-Qualifier Canon .................................................. 206

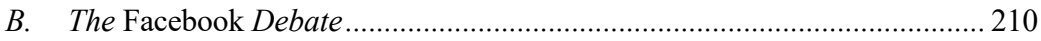

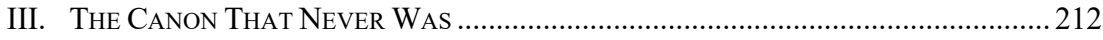

A. A Concise History of the Series-Qualifier Canon ..................................... 212

B. Facebook's Process Error .......................................................................... 218

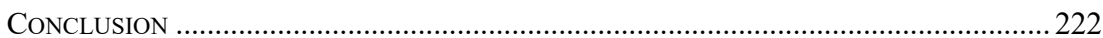

\section{INTRODUCTION}

Textualists like rules. Or, perhaps more accurately, they tend to prefer rule-like ways of approaching interpretive problems. ${ }^{1}$ That may explain why textualists like linguistic canons; these canons "apply rules of syntax to statutes" so that interpreters can "decipher" and "effectuate" the "legislature's intent." 2 This allows interpreters to approach problems "methodically" so that they can "confirm their assumptions about the "common understanding' of words." 3 But to serve that role, a canon needs empirical support to justify that it actually describes how people use or understand language. ${ }^{4}$ After all, the appeal of linguistic canons-from a textualist standpoint - is that they "reflect broader conventions of language use" that are "common in society at large."

1 See Caleb Nelson, What Is Textualism?, 91 VA. L. REv. 347, 350 (2005) (noting "textualists' apparent affinity for rule-like methods of interpretation").

2 Amy Coney Barrett, Substantive Canons and Faithful Agency, 90 B.U. L. REv. 109, 117 \& n.29 (2010). Linguistic canons contrast with "substantive" canons (like the rule of lenity) that "promote policies external to a statute." Id. at 117 . The value of linguistic canons comes, in part, from their purported ability to capture the realities of English usage, see id. at $117 \mathrm{n} .29$, which aids interpreters in identifying an objectified - rather than subjective-legislative intent. See id. at $121 \mathrm{n} .52$ (observing that textualists find value in linguistic canons because they help determine "how a statutory provision would be understood by a skilled user of the language"); Antonin Scalia, Common-Law Courts in a Civil-Law System: The Role of United States Federal Courts in Interpreting the Constitution and Laws, in A MATTER OF INTERPRETATION: FEDERAL COURTS AND the LAW 3, 17 (Amy Gutmann ed., new ed. 2018) (arguing that textualism pursues "objectified" legislative intent).

${ }^{3}$ Facebook, Inc. v. Duguid, 141 S. Ct. 1163, 1170 n.5 (2021).

${ }^{4}$ See, e.g., id. at 1174 (Alito, J., concurring) ("The strength and validity of an interpretive canon is an empirical question...."); Barrett, supra note 2, at 117 n.29 ("If one could demonstrate, through empirical research or otherwise, that Congress does not write statutes against the backdrop of these supposedly shared conventions, the rationale for their existence would evaporate.").

${ }^{5}$ Nelson, supra note 1, at 383; see also Barrett, supra note 2, at 117 n.29, 121 n.52. 
Some linguistic canons are justified by reference to rules of grammar. ${ }^{6}$ That makes sense: Formal grammar tries to describe how ordinary people use language, ${ }^{7}$ and there are even reasons to believe that every humanregardless of language - shares some innate, universal grammar that is built into our brains. ${ }^{8}$ Insights about shared grammatical conventions can go a long way toward guiding interpreters to resolve ambiguities in a way that aligns with general (as opposed to idiosyncratic) usage or understanding. Grammatical rules, then, have a lot of potential to help interpreters achieve textualism's goal: identifying "a sort of 'objectified' intent."

But some canons purport to rest on descriptive grammatical grounds when they do no such thing. These supposed linguistic canons are dangerous. Judges and lawyers are busy people, and they are not (generally speaking) trained linguists. As a result, there are good reasons to think that judges and lawyers lack the time and expertise to confirm or disprove the inherited wisdom that a supposedly linguistic canon describes reality. Sometimes, however, mere common sense - "a fortunate (though not inevitable) sidebenefit of construing statutory terms fairly" 10 - sounds the alarm that a problem is afoot with a supposedly linguistic canon.

This just recently occurred at the Supreme Court. In Facebook $v$. Duguid, an eight-Justice majority led by Justice Sotomayor sparred with Justice Alito over the so-called series-qualifier canon. ${ }^{11}$ Per the majority, this canon is an "interpretative rule" rooted in "rules of grammar." 12 The canon provides that " $[\mathrm{w}]$ hen there is a straightforward, parallel construction that involves all nouns or verbs in a series,' a modifier at the end of the list 'normally applies to the entire series." "13 A colorful example from Justice Kagan illustrates the principle: If a friend says she wants to meet "an actor, director, or producer involved with the new Star Wars movie," you will likely understand that she wants to meet a member of the Star Wars cast, not

\footnotetext{
${ }^{6}$ See, e.g., Facebook, 141 S. Ct. at 1169 (series-qualifier canon); Barnhart v. Thomas, 540 U.S. 20, 26 (2003) (Scalia, J.) (last antecedent rule). Because this Essay is from a textualist perspective, I denote throughout when judicial authority is authored by one of the Supreme Court's textualists. See infra notes 22, 24 and accompanying text (identifying textualist or textualist-leaning justices).

7 See Bryan A. Garner, The Chicago Guide to Grammar, Usage, And Punctuation 1 (2016).

${ }^{8}$ See Kersti BÖRJARS \& KATE BURRIDGe, InTROducing ENGLISH Grammar 10-11 (Routledge 2d ed. 2010) (describing the universal grammar theory).

9 Scalia, supra note 2, at 17.

10 Abramski v. United States, 573 U.S. 169, 179 (2014) (Kagan, J.).

11 Compare Facebook, 141 S. Ct. at 1173-75 (Alito, J., concurring) (questioning the canon's use and identifying situations when the canon does not apply), with id. at 1169, $1170 \mathrm{n} .5$ (majority opinion) (responding to Justice Alito's concerns).

${ }^{12}$ Id. at 1169 (majority opinion).

13 Id. (quoting ANTONIN SCALIA \& BRYAN A. GARNER, READING LAW: THE INTERPRETATION OF LEGAL TEXTS 147 (2012) (alteration in original)).
} 
just any actor. ${ }^{14}$ Whereas the Facebook majority found this canon useful for cutting through a knotty textual problem that sharply divided the courts of appeals, ${ }^{15}$ Justice Alito concurred only in the judgment because of the majority's overreliance on this canon, which he feared was being used in too much of a rule-like manner despite intuitive reasons to doubt its force. ${ }^{16}$

The Facebook debate tees up an important discussion about the socalled series-qualifier canon. The canon's basic justification is syntactic; it purports to be a rule about "the structure of sentences and phrases." ${ }^{17}$ But in fact, the canon necessarily rests on threshold judgments about semantics, i.e., "the meaning of words and how these meanings combine when words are combined into phrases and sentences." 18

Recognizing the proper role of semantic judgment lends support to much of Justice Alito's qualified criticism of the series-qualifier canon in Facebook. ${ }^{19}$ It also accords with the canon's origins. This Essay aims to show that the Facebook majority's series-qualifier canon is a distorted outgrowth of a much narrower principle. Whereas the canon as it exists today purports to describe general syntactic use, ${ }^{20}$ the authorities on which it rests stand for no such rule. Rather, the series-qualifier canon evolved from a principle that was not used to resolve structural ambiguities with syntactic rules at the outset; its narrower domain was to confirm, after making a threshold semantic judgment, that certain ways of reading a sentence are grammatical. ${ }^{21}$ In Facebook, the majority used the canon to do the former, not the latter, and that appropriately set off alarm bells for Justice Alito. I, therefore, refer to the canon as "so-called" because it is the more limited historical principle - not the contemporary successor that the Court applied in Facebook - that warrants adherence as a fundamental maxim of interpretation.

This Essay proceeds in three parts. Part I describes the modern Supreme Court's textualist commitments and explains how those commitments could lead to overformalization. Part II describes the modern series-qualifier canon and the debates among the Justices in Facebook about its role. Part III tells the story of the canon's origin and then uses that history to further inform the

\footnotetext{
${ }^{14}$ Lockhart v. United States, 577 U.S. 347, 362 (2016) (Kagan, J., dissenting) (internal quotation marks omitted)

15 See Facebook, 141 S. Ct. at 1168 \& n.4.

16 See id. at 1173-75 (Alito, J., concurring).

17 BÖRJARS \& BURRIDGE, supra note 8, at 13.

18 Id.

19 See 141 S. Ct. at 1173-75 (Alito, J., concurring).

20 See infra Section II.A.

${ }^{21}$ See infra Section III.A.
} 
points Justice Alito advanced in his Facebook concurrence. The Essay makes two central claims: (1) as a descriptive matter, Justice Alito properly identified a process error in how the Facebook majority used the seriesqualifier canon; and (2) as a normative matter, errors of this sort threaten textualism's core commitments and goals.

\section{MOdERn TeXtualist COMMitMENTS}

\section{A. Textualism in Action at the Supreme Court}

In recent decades, textualism has "gained considerable prominence within the federal judiciary," particularly on the Supreme Court, even as legal scholars remain skeptical or dismissive. ${ }^{22}$ What textualism "is" has already received significant theoretical attention, ${ }^{23}$ and there is no need to rehash the answer at length. For purposes of this Essay, it suffices to describe what leading modern judicial textualists do (or at least purport to do) with statutory interpretation.

Justice Scalia, one of "the clearest and most influential voices" for modern textualism, ${ }^{24}$ described textualism's goal as identifying "a sort of 'objectified' intent - the intent that a reasonable person would gather from the text of the law, placed alongside the remainder of the corpus juris." ${ }^{25}$ The focus is not on subjective intent - e.g., the "intent of the legislature" - but on the meaning a reasonable person would be authorized to understand that the legislature intended with its chosen words. ${ }^{26}$ One way to privilege objectified over subjective intent is to read statutes through the lens of ordinary English usage, i.e., to focus on how people in the relevant community ordinarily use and understand language. ${ }^{27}$ Thus, for example, a hallmark of the current

22 See Tara Leigh Grove, Which Textualism?, 134 HARV. L. REV. 265, 265 (2020). A majority of current Supreme Court Justices are generally regarded (or self-identify) as textualist or textualist-leaning. See id. at 265 n.1 (Justice Kagan); id. at 266 (Justice Gorsuch); id. at 283 (Justice Thomas); id. at 288 n.152 (Chief Justice Roberts and Justice Alito); id. at 292 (then-Judge Barrett); see also, e.g., Brett M. Kavanaugh, Fixing Statutory Interpretation, 129 HARV. L. REV. 2118, 2118 (2016) (reviewing ROBERT A. KATZMANN, JUdGing StATUTES (2014)) (advancing textualist commitments).

23 See generally, e.g., Grove, supra note 22 (identifying competing textualisms); John F. Manning, What Divides Textualists from Purposivists?, 106 CoLUM. L. REV. 70 (2006) (distinguishing textualism from purposivism, its main methodological competitor); Nelson, supra note 1 (analyzing textualism's foundations).

24 John F. Manning, Textualism as a Nondelegation Doctrine, 97 COLUM. L. REV. 673, 685 (1997).

25 Scalia, supra note 2, at 17.

26 See id. at 16-17.

27 See, e.g., Barrett, supra note 2, at $121 \mathrm{n} .52$ (noting that linguistic canons have value because they "are rules of thumb about how English speakers use language"); Frank H. Easterbrook, What Does Legislative History Tell Us?, 66 CHI.-KENT L. REV. 441, 443 (1990) ("Textualists, like other users of language, want to know its context, including assumptions shared by the speakers and the intended audience."). 
Supreme Court's textualism is an emphasis on the ordinary public meaning of words at the time of enactment. ${ }^{28}$

Notably, textualist inquiry is contextual. ${ }^{29}$ If textualism measures objectified intent by reference to the remainder of our law, then it necessarily focuses on the text but looks beyond the text for cues about meaning. ${ }^{30}$ And those cues can come from a lot more places than just a dictionary or grammar book. ${ }^{31}$ Today's textualists attempt to divine the ordinary meaning of statutes from broader statutory and legal context, as well as the statute's structure, history, and purpose, all read through the lens of basic common sense..$^{32}$ Textualism - at least in theory-is not literalism. ${ }^{33}$ Context matters.

But context is where deep divisions can arise. Professor Tara Leigh Grove recently argued that the Supreme Court's textualists switch between how much emphasis they place on semantic context (what Professor Grove calls "formalistic" textualism) and on social context (what she calls "flexible" textualism) ${ }^{34}$ In other words, the Supreme Court's textualists are inconsistent about the weight they place on different contextual cues, such as semantic or syntactic rules on the one hand and reasonable social expectations on the other. ${ }^{35}$ These different approaches might explain, for example, the recent divisions in Bostock v. Clayton County concerning whether Title VII prohibits an employer from terminating an employee simply for being homosexual or transgender. ${ }^{36}$ Each opinion in that case tried

28 See, e.g., Bostock v. Clayton Cnty., 140 S. Ct. 1731, 1738 (2020) (Gorsuch, J.) (looking for the "ordinary public meaning" of Title VII's prohibition on discrimination because of "sex"); New Prime Inc. v. Oliveira, 139 S. Ct. 532, 539 (2019) (Gorsuch, J.) (looking for the ordinary meaning of "contract of employment"). To be sure, textualists can share this commitment but disagree about how to identify ordinary public meaning. See infra notes 34-39 and accompanying paragraph.

${ }^{29}$ See, e.g., Grove, supra note 22, at 269 \& n.27 (arguing that "emphasis on semantic context," particularly as compared to "social or policy context," is "an important distinction among textualisms"); Manning, supra note 23, at 76 (arguing that emphasis on semantic context distinguishes textualism from purposivism, which focuses on policy context); Easterbrook, supra note 27, at 443 (noting that textualists want to know language's "context").

${ }^{30}$ Cf. Scalia, supra note 2, at 17-18.

31 See, e.g., Torres v. Lynch, 136 S. Ct. 1619, 1626 (2016) (Kagan, J.) (warning against just "staring at, or even looking up, the words" at issue); Barnhart v. Thomas, 540 U.S. 20, 26 (2003) (Scalia, J.) (noting that a grammatical rule "is not an absolute and can assuredly be overcome by other indicia of meaning")

32 See, e.g., Abramski v. United States, 573 U.S. 169, 179 (2014) (Kagan, J.).

33 See, e.g., Scalia, supra note 2, at 24 (stating that a "good textualist is not a literalist," but also not "a nihilist"); Grove, supra note 22, at 291 ("Modern textualists insist that the method is not literalism.").

34 See Grove, supra note 22, at 266-67, 279-90.

35 See, e.g., id. at 290 n.167 (noting that "no self-proclaimed textualist on the Supreme Court has clearly signed on to one version of textualism" and citing votes by Chief Justice Roberts and Justices Thomas and Kagan as evidence of variation in approach).

36140 S. Ct. 1731, 1737 (2020) (Gorsuch, J.). 
to claim the textualist mantle, ${ }^{37}$ at least insofar as textualism is committed to legislative supremacy and constraining judicial discretion. ${ }^{38}$ But whereas Justice Gorsuch's majority opinion approached the problem formalistically with an emphasis on semantic context, Justice Alito's (joined by Justice Thomas) and Justice Kavanaugh's separate dissents placed greater emphasis on how social and cultural context informed ordinary public meaning. ${ }^{39}$ As Bostock shows, some textualists might be more formalistic than others.

\section{B. Canons and the Risk of Over-Formalization}

These divisions create problems for reliance on linguistic canons. At a high level, an interpretative canon is a rule or maxim that is regarded as "fundamental." 40 As Judge Easterbrook (a "prominent textualist" ${ }^{41}$ ) has argued, "canons are inevitable, because all language depends on them." ${ }^{\prime 2}$ But he remains "skeptical" of canons because they all implicitly recognize that context can override whatever default rule they provide. ${ }^{43}$ And possible

37 See, e.g., id. at 1738 (Gorsuch, J.) ("If judges could add to, remodel, update, or detract from old statutory terms inspired only by extratextual sources and our own imaginations, we would risk amending statutes outside the legislative process reserved for the people's representatives."); id. at 1761 (Alito, J., joined by Thomas, J., dissenting) (criticizing the majority's "purport[ed] . . purest and highest form of textualism" because its argument "effectively amends the statutory text"); $i d$. at 1823 (Kavanaugh, J., dissenting) ("Under the Constitution's separation of powers, our role as judges is to interpret and follow the law as written, regardless of whether we like the result.").

${ }^{3}$ Cf., e.g., John F. Manning, Justice Scalia and the Idea of Judicial Restraint, 115 Mich. L. REV. 747, 754 (2017) (reviewing ANTONIN SCALIA, A MATTER OF INTERPRETATION: FEDERAL COURTS AND THE LAW (1997) (noting that textualists "invoke concerns about judicial subjectivity as a way to justify textualism"); Grove, supra note 22, at 293 ("For many early textualists, the goal was not only to preserve legislative supremacy but also to constrain judicial discretion."); Barrett, supra note 2, at 113 (noting textualist adherence to "the principle that federal courts must function as Congress's faithful agents"); Nelson, supra note 1, at 403 (noting that textualists are less "receptive to a background presumption of judicial discretion").

${ }^{39}$ See, e.g., Bostock, 140 S. Ct. at 1740-41 (Gorsuch, J.) (focusing on semantic clues of Congress's intent to protect individuals over groups); id. at 1754-55 (Alito, J., and Thomas, J., dissenting) (pointing to extra-textual clues about Congress's understanding of Title VII); id. at 1828 (Kavanaugh, J., dissenting) (arguing that as "commonly understood, sexual orientation is distinct from, and not a form of, sex discrimination"); Grove, supra note 22, at 281-85.

40 See Canons of Construction, BLACK's LAW Dictionary (6th ed. 1990).

${ }^{41}$ Richard H. Fallon, Jr., The Statutory Interpretation Muddle, 114 Nw. U. L. REV. 269, 290 n.71 (2019); accord, e.g., Grove, supra note 22, at 273; Manning, supra note 24, at 685; see also Frank H. Easterbrook, The Case of the Speluncean Explorers: Revisited, 112 HARV. L. REV. 1913, 1913 (1999) (advancing a textualist defense of reading statutes in light of widely accepted background legal principles) [hereinafter Easterbrook, Speluncean Explorers]; Easterbrook, supra note 27, at 443 (defending a socially contextualized approach to textualism); Frank H. Easterbrook, The Role of Original Intent in Statutory Construction, 11 HARV. J.L. \& PUB. POL'Y 59, 60 (1988) ("The words of the statute, and not the intent of the drafters, are the "law."').

42 Frank H. Easterbrook, The Absence of Method in Statutory Interpretation, 84 U. CHI. L. REV. 81, 84 (2017).

43 See id. at 83 . 
contexts abound: There is linguistic, intratextual, and economic context; ${ }^{44}$ there is social context, drawn from "familiarity with American history and culture", ${ }^{45}$ and there is policy context, the favored tool of the purposivist, which looks at "the mischief being remedied." ${ }^{46}$ Surely there are others, too. So, the issue with canons is that applying them - or predicting how they will be applied - depends on which context(s) an interpreter thinks matter(s), and how much weight each context receives relative to others.

One potential solution to this problem is to embrace formalism. A rulelike and formalistic interpretative approach may be, as Professor Grove has argued, more likely to constrain judicial discretion and thereby preserve legislative supremacy and judicial legitimacy_values that are central to contemporary textualism. ${ }^{47}$ Thus, she advocates a "formalistic textualism" that is "relatively rule-bound" and "emphasizes semantic context, rather than social or policy context, and downplays the practical consequences of a decision." 48

These ideals are attractive to many, and I do not quibble with them here. But the appeal of formalistic textualism may lead interpreters to overformalize their approach. For example, if we are told that a particular canon reflects actual grammatical use, textualists committed to legislative supremacy may have the temptation to rely on that canon as particularly instructive relative to nonlinguistic contexts that can also properly inform meaning. In pursuit of formalism and in service to textualism's underlying commitments, interpreters may fairly conclude that, where such a purportedly linguistic canon applies, only other linguistic contexts can trump its application. But if the canon does not actually reflect grammatical reality

\footnotetext{
${ }^{44}$ Id.; see also Easterbrook, Speluncean Explorers, supra note 41, at 1913 (noting that language "takes meaning from its linguistic context").

45 Grove, supra note 22, at 280; cf. Easterbrook, Speluncean Explorers, supra note 41, at 1913 ("historical and governmental contexts" matter in textual interpretation); Easterbrook, supra note 27, at 443 ("language is a social enterprise" that can draw meaning from "assumptions shared by the speakers and the intended audience").

46 Manning, supra note 23, at 76.

47 Grove, supra note 22, at 290-307; see also, e.g., Scalia, supra note 2, at 25 (calling criticism of formalistic interpretation "mindless" because formalism "is what makes a government a government of laws and not of men"); cf. supra notes 37-38 and accompanying text (advancing textualist arguments by reference to democratic values and a restrained judicial role). But see, e.g., Samuel L. Bray, The Mischief Rule, 109 GEO. L.J. 967, 988 n.111 (2021) (arguing that "relying on context ... can allow judges to temper their creativity and lessen legislative surprise at their interpretations").

${ }^{48}$ Grove, supra note 22, at 269. Although "semantic context" might be taken to refer only to understanding the meaning of particular words and phrases, I understand it to encompass syntactic conventions as well, as these also explain the way a reasonable person would use language under the circumstances. See Manning, supra note 23, at 91 (defining "semantic context"); Fallon, supra note 41, at 272 (noting that "semantic meaning" is "defined largely by the definitions of words and the rules of syntax and grammar" (emphasis added)).
} 
(i.e., if it is not really linguistic), then the interpreter may inadvertently err by paying insufficient attention to other relevant contexts-including, perhaps, rules that actually inform linguistic meaning - thereby potentially undermining what the legislature communicated. Put more simply, the temptation of formalism may lead interpreters to reflexively embrace supposedly linguistic canons over other interpretive cues without appropriately discerning whether the canon is all that it claims to be. ${ }^{49}$ As the subsequent Parts argue, that is the trap into which the Facebook majority may have fallen.

\section{CONCERNS WITH THE SERIES-QUALIFIER CANON}

\section{A. Understanding the Series-Qualifier Canon}

Before turning to the debate in Facebook, it will help to explain the socalled series-qualifier canon in more detail. As recited by the Supreme Court, this canon provides that " $[\mathrm{w}]$ hen there is a straightforward, parallel construction that involves all nouns or verbs in a series,' a modifier at the end of the list "normally applies to the entire series." ${ }_{50}$

To understand this canon's role, we need to start with some light background in linguistics. We use language all the time in ways that create ambiguity. Where syntax causes the problem, that ambiguity is "structural." Sometimes the structural ambiguity is unresolvable using only the single sentence. For instance, the lone sentence "They are cooking apples" is ambiguous because you cannot know whether "they" are people who are "cooking" apples (i.e., pronouns acting on a noun) or whether "they" are "apples" with the purpose of being cooked (i.e., pronouns linked to a subjective complement noun). To resolve the ambiguity, you need additional context from outside of the sentence itself, such as whether the question prompting the sentence is "What are they doing?" versus "What are they?"

\footnotetext{
${ }^{49}$ Indeed, it is not necessarily uncommon for interpretative rules or conventions to be presented unquestioningly as "grammatical" without much basis for that claim. Compare, e.g., Barnhart v. Thomas, 540 U.S. 20, 26 (2003) (Scalia, J.) (calling the last antecedent rule "grammatical"), with, e.g., Joseph Kimble, The Doctrine of the Last Antecedent, the Example in Barnhart, Why Both Are Weak, and How Textualism Postures, 16 SCRIBes J. Legal Writing 5, 13 (2015) (arguing that the "grammatical analysis" behind part of the last antecedent rule "is rather hazy").

${ }^{50}$ Facebook, Inc. v. Duguid, 141 S. Ct. 1163, 1169 (2021) (quoting SCALIA \& GARNER, supra note 13, at 147 (alteration omitted)). As presented in Scalia and Garner's Reading Law treatise, the canon provides the same result for prepositive modifiers (i.e., those preceding a qualifying parallel construction of nouns or verbs). See SCALIA \& GARNER, supra note 13, at 147. That proposition is not in tension with linguistic principles or interpretative history in the way the postpositive claim is, and so I do not address that aspect of the canon.

51 See BÖRJARS \& BURRIDGE, supra note 8, at 24.
} 
But sometimes we can overcome structural ambiguity using just the sentence itself. The lone sentence "The cop saw the thief using a telescope" is ambiguous because the postpositive modifier "using a telescope" could mean that the cop used a telescope to see the thief or that the cop observed the thief's use of a telescope. Yet other sentences with the same structure, but different words, seem clearer to us. "The cop saw the thief using a gun" has an intuitive meaning: The thief used the gun, and the cop saw the thief use it. We reach this conclusion because of semantics; we know the meaning of "saw" and the meaning of "gun," and we do not typically associate a gun as a tool for seeing. For simplicity, I describe this as a lack of a "semantic match" between the words "saw" and "gun." 52

But what if I were trying to convey that the cop was ensconced atop a building, and she used the scope mounted on a rifle to observe the thief? If that were my purpose, then the sentence is ungrammatical not in the abstract but only with respect to its ability to convey my intended meaning. ${ }^{53}$ To be sure, I structured the sentence in a way that can convey my intended message, but I failed to convey what I intended to convey because the recipient is likely to process my message as "the cop saw, with her eyes, the thief who was using a gun." My central point is this: In many situations, the way we resolve structural ambiguity using only a sentence is through semantics; our understanding of discrete words informs how we process the structure.

This leads to another important distinction. Today's textualism tries to identify how an ordinary, reasonable person would understand language. ${ }^{54}$ That is a question about how we process language, not necessarily about how we use it. So, canons that rest on prescriptions about how best to speak, or even that purport to describe how people actually speak, do not necessarily address the right issue: how people make sense of what is said to them. When we talk about the utility of particular linguistic canons, we must keep in mind the distinction between structures that are possible (i.e., capable of being understood to convey the intended meaning) versus understandings that are ordinary (i.e., how the ordinary person is likely to process the structure). Canons that shed light on the latter have more robust utility than those that just identify the former.

\footnotetext{
52 I am borrowing "semantic matching" from computer science, where the term describes identifying correspondences using semantic meaning. See Fausto Giunchiglia \& Pavel Shvaiko, Semantic Matching, 18 KNOWLEDGE ENG'G REV. 265, 265 (2004).

${ }^{53}$ Cf., e.g., BÖRJARS \& BURRIDGE, supra note 8, at 31 . In this example, we would say that "the thief using a gun" is not a constituent (i.e., a group of words that "go together") of the sentence, and the sentence is ungrammatical only insofar as it conveys otherwise. See id. at 22, 31.

54 See, e.g., Bostock v. Clayton Cty., 140 S. Ct. 1731, 1738 (2020) (Gorsuch, J.); New Prime Inc. v. Oliveira, 139 S. Ct. 532, 539 (2019) (Gorsuch, J.).
} 
Some linguistic canons do well to describe the ordinary. Consider the series-qualifier canon's cousin, the last antecedent rule, which has been justified by reference to grammatical rules prescribing where to place modifiers to best avoid structural ambiguity. ${ }^{55}$ That supposedly "grammatical" rule provides that "a limiting clause or phrase ... should ordinarily be read as modifying only the noun or phrase that it immediately follows." ${ }_{56}$ Thus, as the Supreme Court has reasoned, parents who warn their teenage son, "You will be punished if you throw a party or engage in any other activity that damages the house" have proscribed (1) any party, not just one that damages the house, and (2) any other activity that damages the house. ${ }^{57}$ Like other linguistic conventions, the last antecedent rule "is not an absolute and can assuredly be overcome by other indicia of meaning," 58 i.e., context. And that makes sense; "we know that grammatical rules are bent and broken all the time," ${ }^{59}$ so we cannot cling to the idea that the ordinary way people use and understand English always lines up with prescriptive rules. But even if the last antecedent rule does not perfectly describe how we use language, it has a pretty good grounding in how people process language. Psycholinguistic evidence suggests that there is a tendency to understand a modifier as referring to its last antecedent, just as the rule tells us. ${ }^{60} \mathrm{Put}$ simply, the rule tells us which possible structure is the way we ordinarily understand language.

The series-qualifier canon appears to be in tension with the well-settled last antecedent rule. But that appearance is somewhat superficial. A traditional formulation of the last antecedent rule is: "Referential and

55 See Payless Shoesource, Inc. v. Travelers Cos., 585 F.3d 1366, 1371 (10th Cir. 2009) (Gorsuch, J.).

56 Barnhart v. Thomas, 540 U.S. 20, 26 (2003) (Scalia, J.).

$57 \mathrm{Id}$. at 27 (internal quotation marks omitted). Whether one finds this structural reasoning persuasive is a different matter. A fair response to this argument is that the word "other," as used in this example, usually implies some form of commonality, perhaps suggesting only that parties that damage the house are forbidden. See, e.g., infra note 121 (identifying cases taking this view of the word "other").

58 Barnhart, 540 U.S. at 26 (Scalia, J.).

59 Payless, 585 F.3d at 1371 (Gorsuch, J.).

60 See Martin J. Pickering \& Roger P. G. van Gompel, Syntactic Parsing, in HANDBOOK OF PsychOLINGUistics 455, 486 (Matthew J. Traxler \& Morton A. Gernsbacher eds., 2d ed. 2006) (noting that "[o]ne structural factor about which there is striking agreement among researchers is recency: People prefer to attach a new phrase to a more recent than a less recent attachment site," meaning that in "ambiguity resolution" people "prefer more local to less local dependencies"); see also, e.g., Guillermo Rodríguez, Relative Clause Attachment Preferences in Second Language Learners' Parsing Performance, 10 U. PA. WORKING PAPERS LINGUISTICS 157, 157 (2004) (reporting the "phenomenon ... referred to as low or late attachment" by which English users tend to attach relative clauses to nearer noun phrases); Colin Phillips \& Edward Gibson, On the Strength of the Local Attachment Preference, $26 \mathrm{~J}$. PSYCHOLINGUISTIC RSCH. 323, 324 (1997) (identifying the "local attachment preference" as "a pervasive phenomenon in parsing"). 
qualifying words and phrases, where no contrary intention appears, refer solely to the last antecedent." ${ }^{61}$ The series-qualifier canon takes that general principle and expresses it in grammatical terms. Thus, the canon identifies certain roles and structures - "a straightforward, parallel construction that involves all nouns or verbs in a series"-and says those words are normally all modified by a later modifier. ${ }^{62}$ In short, the canon appears to define the extraordinary situations in which the last antecedent rule does not apply, and the canon does so by reference to the presence of specific structures (i.e., a series with a straightforward, parallel construction of all nouns or verbs). ${ }^{63}$

But the series-qualifier canon's empirical basis is unclear. As discussed, with respect to postpositive modifiers (i.e., those that come after the modified words), the canon is in tension with the general tendency to process words as attaching to the nearest antecedent. ${ }^{64}$ So the canon must be rooted in either a prescriptive claim about how we should use English or a descriptive claim about how we actually do so. In either situation, it is unclear what the basis is for saying that modification "normally" operates as the canon states. Start with prescription. As I explained at the start of this Section, we often resolve structural ambiguity with semantic judgments, not syntactic ones. That's why the same sentence structure can be clear or ambiguous depending on particular words used, and a structure that conveys an intended meaning in a way that runs contrary to ordinary processing is ungrammatical only in a limited sense. ${ }^{65}$ Thus, English does not need a hardand-fast prescriptive syntactic rule in this context because certain structures are ambiguous or unambiguous depending on the actual words used, not in the abstract. Nor can the canon claim particularly strong descriptive force, given the common problem of misplaced modifiers. ${ }^{66}$ In short, it is not clear what makes the series-qualifier canon rise to the level of a fundamental rule or maxim about how people use or understand English, as opposed to a general principle of what is possible for people to do in a way that is understandable.

61 2A Norman Singer \& Shambie Singer, Sutherland Statutes AND Statutory CONSTRUCTION $\S 47: 33$ (7th ed. 2020).

62 See SCALIA \& GARNER, supra note 13 , at 147.

63 Accord, e.g., Jama v. ICE, 543 U.S. 335, 344 n.4 (2005) (Scalia, J.) (suggesting that cases applying a version of what is now called the series-qualifier canon "rebut the last antecedent inference" only because they involve specific sentence structures).

64 See supra note 60 and accompanying text (noting the consensus in psycholinguistic research that people prefer to attach a new phrase to the closest attachment site, i.e., the nearer antecedent).

65 See supra notes 52-54 and accompanying paragraphs.

66 See, e.g., Colette A. Daiute, Psycholinguistic Foundations of the Writing Process, 15 RsCH. TEACHING ENG. 5, 13 (1981) (reporting that in a study of faulty sentences, modifier errors were "frequent”); Payless Shoesource, Inc. v. Travelers Cos., 585 F.3d 1366, 1371 (10th Cir. 2009) (Gorsuch, J.) (observing the tendency to misplace modifiers). 


\section{B. The Facebook Debate}

Despite these issues, the series-qualifier canon recently all but decided a case at the Supreme Court, although not without some controversy. Facebook v. Duguid addressed the Telephone Consumer Protection Act's definition of an autodialer, which in relevant part must be able "to store or produce telephone numbers to be called, using a random or sequential number generator." ${ }^{67}$ Everyone agreed that "using a random or sequential number generator" modified "produce"; the issue was whether it modified "store," too. ${ }^{68}$

In an opinion by Justice Sotomayor, an eight-justice majority began its textual analysis with the series-qualifier canon. ${ }^{69}$ Calling the canon a "conventional rule[] of grammar" that "generally reflects the most natural reading of a sentence," the Court started from the premise that the "most natural construction" is to read the modifier as applying to "store" as well as "produce." "70 That is, the Court started with a structural judgment based on a syntactic rule. Of course, the Court did not end there; it marched through additional textual cues that confirmed its reading, including the nature of the modified clause, use of punctuation, and broader statutory context. ${ }^{71}$

Justice Alito concurred in the judgment. Although he agreed with the majority's interpretation, he expressed concern over "the Court's heavy reliance" on the series-qualifier canon. ${ }^{72}$ As an initial matter, he objected that the majority treated the canon as too rule-like, noting that the canon has wellaccepted limitations. ${ }^{73}$ Justice Alito then highlighted several examples that, in his view, call into question the Court's claim that the canon generally reflects the most natural reading of a sentence. ${ }^{74}$ Then Justice Alito got to the heart of the matter: how "common understanding" informs the way we read words. ${ }^{75}$ Rejecting the view that statutory interpretation can be reduced "to a series of if-then computations" with canons, Justice Alito emphasized instead "our common understanding" of social reality and familiarity with

\footnotetext{
6747 U.S.C. $\$ 227(a)(1)$.

${ }^{68}$ Facebook, Inc. v. Duguid, 141 S. Ct. 1163, 1169 (2021).

${ }^{69} \mathrm{Id}$.

${ }^{70} \mathrm{Id}$.

71 See id. at $1169-73$.

72 Id. at 1173 (Alito, J., concurring).

73 See id. at 1173-74 (noting that "the Scalia-Garner treatise makes it clear that interpretive canons 'are not "rules" of interpretation in any strict sense but presumptions about what an intelligently produced text conveys"” (quoting SCALIA \& GARNER, supra note 13, at 51)).

74 See id. at 1174 (suggesting that "it is very easy to think of sentences that clearly go against the canon").

${ }^{75} \mathrm{Id}$.
} 
"English prose." ${ }^{76}$ In short, Justice Alito rejected the idea - embraced by the majority - that a syntactic canon can resolve structural ambiguity on its own at the outset. Instead, Justice Alito noted that resolving structural ambiguity often "has little to do with syntax and everything to do with our common understanding" of the world. ${ }^{77}$

The majority responded briefly. Focusing on Justice Alito's final point about common understandings and general familiarity with the English language, the majority justified its reliance on the series-qualifier canon as "using traditional tools of statutory interpretation" to resolve "[d]ifficult ambiguities ... methodically ... in order to confirm" assumptions about common understanding. ${ }^{78}$

The back-and-forth in Facebook is yet another data point that supports Professor Grove's formalistic-versus-flexible textualisms observation. ${ }^{79}$ The majority opinion starts with a rule-like way of cutting through the problem by setting up a presumptive natural reading based on supposed rules about syntax. ${ }^{80}$ All that remains for the rest of the opinion is to march through every other argument and either brand it as supporting the canon's outcome ${ }^{81}$ or deem it insufficiently weighty to overcome the supposed general grammatical rule. ${ }^{82}$ For his part, Justice Alito reprises his role as the flexible textualist from Bostock. ${ }^{83} \mathrm{He}$ again reasons that common understanding, informed by social reality, goes a long way to answering interpretative problems. ${ }^{84}$ Linguistic canons "can help" if the statutory language is "troublesome," but they should not be "rigid rules" that frame the entire analysis. ${ }^{85}$

76 Id. at 1175.

77 Id. at 1174.

78 Id. at 1170 n.5 (majority opinion). In this connection, the majority noted that the Court "often" applies the series-qualifier canon. See id. at 1169 (first citing Paroline v. United States, 572 U.S. 434, 447 (2014), then citing United States v. Bass, 404 U.S. 336, 339-40 (1971)).

79 See generally Grove, supra note 22 (discussing the formalistic and functionalist approaches to textualism); supra notes 34-39 and accompanying text. Cf., e.g., Abbe R. Gluck \& Richard A. Posner, Statutory Interpretation on the Bench: A Survey of Forty-Two Judges on the Federal Courts of Appeals, 131 HARV. L. REV. 1298, 1311-12 (2018) (noting a generational shift in which younger federal appellate judges are more formalistic regardless of political background); Abbe R. Gluck, Justice Scalia's Unfinished Business in Statutory Interpretation: Where Textualism's Formalism Gave Up, 92 NOTRE DAME L. REV. 2053, 2060-72 (2017) (arguing that textualism "has never been fully formalist").

80 See Facebook, 141 S. Ct. at 1169.

81 See id. at 1169-71 (noting the clause's integration, use of punctuation, and statutory context).

82 See id. at 1171-73 (rejecting arguments based on a semantic mismatch between "store" and "generator," the distributive canon, and issues of legislative purpose and policy).

83 Cf. Grove, supra note 22, at 283-85.

84 See Facebook, 141 S. Ct. at 1173-75 (Alito, J., concurring).

85 See id. at 1175. 


\section{THE CANON THAT NEVER WAS}

Justice Alito may have been a lone voice in Facebook, but his qualified criticism of the so-called series-qualifier canon has substantial force. As I explained in Section II.A, there are several reasons rooted in formal linguistics to doubt the weight that the Facebook majority placed on the canon. ${ }^{86}$ But history bears this out, too. The contemporary series-qualifier canon is not a deep-rooted background principle of interpretation; it is an unjustified distortion of a narrower - and more sound - principle borrowed from an English jurist. This final Part provides an overview of that history and how the Supreme Court mistakenly broadened the original seriesqualifier principle before again misapplying it in Facebook.

\section{A. A Concise History of the Series-Qualifier Canon}

\section{Tracing the Canon to Its English Roots}

The earliest Supreme Court case applying something that looks like the contemporary series-qualifier canon is Porto Rico Railway, Light \& Power Company v. Mor, ${ }^{87}$ which is also the oldest case that Facebook cites for the canon. ${ }^{88}$ Porto Rico Railway concerned a statute providing jurisdiction over certain "controversies where all of the parties on either side ... are citizens or subjects of a foreign State or States, or citizens of a State, Territory, or District of the United States not domiciled in Porto Rico." ${ }^{89}$ The issue was whether "not domiciled in Porto Rico" applied to the entire phrase preceding it, including "citizens or subjects of a foreign State or States." the Court reasoned that it did: "When several words are followed by a clause which is applicable as much to the first and other words as to the last, the natural construction of the language demands that the clause be read as applicable to all." "91 This is a syntactic judgment about how people structure and understand sentences.

Porto Rico Railway was not decided on a blank slate; it relied on two earlier cases to support its textual rule: Johnson v. Southern Pacific Co. and

${ }^{86}$ See supra notes 64-66 and accompanying paragraph

87253 U.S. 345, 348 (1920).

88 See 141 S. Ct. at 1169.

89 Porto Rico Ry., 253 U.S. at 346.

$90 \mathrm{Id}$.

91 Id. at 348. The Court bolstered its reasoning with policy, concluding that "Congress could not have intended" to grant jurisdiction where "a domiciled alien is a party while denying under similar circumstances jurisdiction where a domiciled American is a party." Id. at 349. 
United States v. Standard Brewery. ${ }^{92}$ But neither of those cases supported Porto Rico Railway's sweeping claim about sentence structures.

The older of those cases, Johnson v. Southern Pacific, involved a drafting error. An 1893 act provided that locomotive cars be "equipped with couplers coupling automatically by impact, and which can be uncoupled without the necessity of men going between the ends of the cars." ${ }^{93}$ In rejecting the argument that "without the necessity ..." applied only to the act of uncoupling, but not to coupling, the Court determined that there was a missing comma after "uncoupled." 94 Reading the missing comma into the text, "as it should be," the phrase "and which can be uncoupled" was an attribute of the "couplers," and "without the necessity ..." applied to both coupling and uncoupling. ${ }^{95}$ That reasoning - heavily dependent on comma placement - accords with the still-prevailing rule that a "qualifying phrase separated from antecedents by a comma is evidence that the qualifier is supposed to apply to all the antecedents instead of only to the immediately preceding one." ${ }^{96}$ In short, the Court's reasoning seemed to turn on a wholly distinct rule that was not applicable in Porto Rico Railway at all.

The more interesting case is Standard Brewery, which identifies the series-qualifier canon's true origin. Standard Brewery concerned a prohibition on the manufacture and sale of "beer, wine or other intoxicating malt or vinous liquors for beverage purposes." ${ }^{\prime 97}$ At issue was whether the statute prohibited beer containing no more than one-half of one percent of alcohol, which was not "intoxicating" as a matter of law. ${ }^{98}$ In the government's view, this did not matter because "the intention was to include beer and wine whether intoxicating or not." "99 The Court rejected that argument, reasoning that "the framers of the statute intentionally used the phrase 'other intoxicating' as relating to and defining the immediately preceding designation of beer and wine." ${ }^{100}$ For support, the Court borrowed from the English jurist Lord Bramwell: "As a matter of ordinary construction, where several words are followed by a general expression as

\footnotetext{
92 See id. at 348 (first citing United States v. Standard Brewery, 251 U.S. 210, 218 (1920), then citing Johnson v. S. Pac. Co., 196 U.S. 1, 18-19 (1904)).

93 Johnson, 196 U.S. at 13 .

94 Id. at $18-19$

95 See id.

96 SINGER \& SINGER, supra note 61 , at $\S 47: 33$.

97251 U.S. at 218.

$98 I d$. at $215,220$.

99 Id. at 218.

${ }^{100} \mathrm{Id}$.
} 
here, which is as much applicable to the first and other words as to the last, that expression is not limited to the last, but applies to all." 101

Note that Standard Brewery did not deal with the issue presented in Facebook or Porto Rico Railway. Instead, Standard Brewery dealt with a semantic issue about the meaning of the words "beer" and "wine," an issue informed by the meaning of "other intoxicating." But Standard Brewery is interesting because it points us to the ultimate source of what has morphed into the series-qualifier canon: Lord Bramwell's opinion in the English Great Western Railway case.

Great Western Railway was a dispute involving a special statutory easement, ${ }^{102}$ and the case turned on an interpretation of the Land Clauses Consolidation Act. ${ }^{103}$ One railway sought to exercise its statutory easement on another railway's property, but the railway in possession of the property objected that under the Land Clauses Consolidation Act, there could be no "compulsory taking of Land" (i.e., the easement) because the buying railway had not subscribed "the whole of the Capital or estimated Sum for defraying the Expences [sic] of the Undertaking" 104 as the Act required. ${ }^{105}$ The basic issue, as Lord Bramwell saw it, was whether the easement counted as "lands" under the Act. ${ }^{106}$ On that score, the Act defined "lands" as extending to "Messuages, Lands, Tenements, and Hereditaments, of any Tenure." 107 It was with respect to the "of any tenure" language that Lord Bramwell spoke when discussing the "ordinary construction" of sentences. ${ }^{108}$

It is worth walking carefully through Lord Bramwell's analysis. Lord Bramwell set out to determine whether the statutory easement was an incorporeal hereditament and therefore within the Act's definition of "land." 109 Lord Bramwell began by confessing that his first instinct was that hereditaments were included in the statutory definition only if they had some tenure, i.e., that a "tenure" was a requirement, but only for hereditaments. ${ }^{110}$

101 Id. (quoting Great W. Ry. Co. v. Swindon \& Cheltenham Extension Ry. Co. [1884] 9 App. Cas. 787 (HL) 808 (appeal taken from Eng.) (opinion of Bramwell)).

102 Great W. Ry. Co., 9 App. Cas. at 791-92 (opinion of FitzGerald); see id. at 807-08 (opinion of Bramwell).

103 Land Clauses Consolidation Act 1845, 8 \& 9 Vict. c. 18 (Eng.); see Great W. Ry. Co., 9 App. Cas. at 808 (opinion of Bramwell).

104 Land Clauses Consolidation Act $\S 16$.

105 Great W. Ry. Co., 9 App. Cas. At 787.

106 Id. at 807-08 (opinion of Bramwell).

107 Land Clauses Consolidation Act $\S 3$.

108 Great W. Ry. Co., 9 App. Cas. at 808 (opinion of Bramwell).

109 See id. As a bit of background, at common law an incorporeal hereditament referred to interests that "existed only in contemplation of law." E.g., Nat'l Supply Co. v. McLeod, 227 P. 350, 350 (Kan. 1924).

110 Great W. Ry. Co., 9 App. Cas. at 808 (opinion of Bramwell). 
In short, his first instinct was to apply the last antecedent rule. But then Lord Bramwell realized that was not the necessary reading. By analogy to the statement "horses, oxen, pigs, and sheep, from whatever country they may come," he realized that "a general expression" at the end of "several words" can sometimes be "as much applicable to the first and other words as to the last." "111 In fact, he thought it would have been nonsensical to limit "of any tenure" only to hereditaments because other items on the list readily match the phrase, too. ${ }^{112}$ So, Lord Bramwell arrived at the conclusion that "of any tenure" referred to each item on the list but as a "general expression" of breadth rather than a strict requirement that there be some tenure. ${ }^{113}$

Focus on what Lord Bramwell did not do. He did not start his analysis with the sentence's structure; his structural point arose only after he concluded that "of any tenure" was a semantic match with every item on the list. ${ }^{114}$ As he says, the "ordinary construction"-i.e., his claim about understanding sentences - applies where the "general expression ... is as much applicable to the first and other words as to the last." 115 Thus, Lord Bramwell's syntactic observation only bolsters his implicit prior semantic conclusion: There is a semantic match between "of any tenure" and each of "messuages, lands, tenements, and hereditaments," and it is not ungrammatical to read the modifier as attaching to each antecedent. Note also that "of any tenure" is not just any qualifier; it is an expression of breadth and one that is "general." 116 Lord Bramwell's limited principle is that where an integrated list ends with a broad, general expression that semantically matches every item on the list, it is "ordinary" to construe the expression as applicable to the entire list. ${ }^{117}$

Lord Bramwell's claim should not be haphazardly extended beyond the situation before him: an integrated list ending with a broad qualifier that semantically matches each item on the list. Indeed, even the example to which he analogizes follows the same convention as the statute he interprets. ${ }^{118}$ Thus, Lord Bramwell's observation applies to "wines and

\footnotetext{
111 Id. (internal quotation marks omitted).

112 See id. ('If the general expression is limited to 'hereditaments,' then it does not extend to messuages, lands, and tenements, except as included in hereditaments, which cannot be the case.").

113 See id. ("[T] he general words apply to those of the antecedent to which they are applicable and not to the others, and the words are to be read as 'of whatever tenure, if any."').

114 See id.

115 Id.

116 Id.

117 See id. at 808-09.

118 See id. (analogizing to "horses, oxen, pigs, and sheep, from whatever country they may come"). Of note, the statute and Lord Bramwell's example both set off the qualifier with a comma, which under
} 
cheeses of any age" or "justices, judges, and magistrates of whatever methodological commitment." In each example, the postpositive modifier is (1) a semantic match to each item on the list and (2) broad and inclusive (because of the words "any" and "whatever"). But Lord Bramwell never speaks to issues like "Englishmen, Canadians, and Americans not domiciled in the United States," which ends with a restrictive phrase that semantically matches each of the three nationalities, but which also could identify only a subset of Americans with something likely in common with Englishmen and Canadians (i.e., not being domiciled in the United States). In that last example, Lord Bramwell might simply tell us that we need another cue to make a final interpretation, like the presence or absence of a comma after "Americans." 119 His principle, however, does not necessarily supply an answer on its own.

\section{How the Supreme Court Went Astray}

On this side of the Atlantic, the nuance of Lord Bramwell's analysis was lost. Standard Brewery extended Lord Bramwell's observation to a new context, albeit one that still made linguistic sense. ${ }^{120}$ A reference to "other intoxicating" beverages at the end of a list does imply that the preceding "beer" and "wine" refers to intoxicating versions of those drinks. But that is because of the semantic meaning of "other," not just syntax. ${ }^{121}$

The real culprit in distorting Lord Bramwell's syntactic observation was Justice Brandeis's Porto Rico Railway opinion. ${ }^{122}$ Indeed, Justice Brandeis made two significant changes in reciting Lord Bramwell's narrow principle. Whereas Lord Bramwell was concerned with a "general expression," 123 Justice Brandeis broadened the rule to encompass any "clause." 124 So, while Lord Bramwell was speaking about statements of breadth, ${ }^{125}$ Justice Brandeis extended the rule to restrictive modifiers as well. And whereas Lord Bramwell spoke of what "ordinary construction"

\footnotetext{
a different interpretative convention suggests application to all antecedents. See supra note 96 and accompanying text. But Lord Bramwell did not appear to attach significance to the comma.

119 Cf. supra note 96 and accompanying text.

120 See supra notes $97-101$ and accompanying text.

121 See, e.g., NOAA Md., LLC v. Adm'r of the Gen. Servs. Admin., 997 F.3d 1159, 1168 (Fed. Cir. 2021) (stating that the "word "other' ... suggests a commonality of theme"); Transco Expl. Co. v. Pac. Emps. Ins. Co., 869 F.2d 862, 865 (5th Cir. 1989) (observing that "normally the word 'other' is to be used only when comparing things belonging to the same group").

122 See Porto Rico Ry., Light \& Power Co. v. Mor, 253 U.S. 345, 348 (1920).

123 Great W. Ry. Co., 9 App. Cas. at 808 (opinion of Bramwell).

124 Porto Rico Ry., 253 U.S. at 348.

125 See supra notes 116-117 and accompanying text.
} 
permits, ${ }^{126}$ Justice Brandeis spoke of what a "natural construction... demands." 127 Thus, Porto Rico Railway recites a rule broader in scope and stricter in application than Lord Bramwell's principle. That change is justified neither by Standard Brewery nor Johnson, on which Porto Rico Railway relies. ${ }^{128}$ Nor did Justice Brandeis articulate any other linguistic basis for his formulation. Perhaps he was simply inattentive, or perhaps he just needed to make a forceful rhetorical point to persuade others of his position. While the reasons for the revision are unclear, the consequence is not: The Supreme Court has come to treat a misstatement as a rule. ${ }^{129}$

This was not inevitable. Before Facebook, the Supreme Court generally recognized that Porto Rico Railway's so-called rule applied only very narrowly. In United States v. Bass, the Court made the semantic judgment that "in commerce or affecting commerce" is a semantic match for the verbs "receives," "possesses," and "transports," and then applied the Porto Rico Railway rule to conclude that "the more plausible construction here is that it in fact applies to all three"-something the Court conceded was just the "beginning" of its reasoning because "the argument is certainly neither overwhelming nor decisive." 130 Decades later, the Court cast the Porto Rico Railway rule as just a means "to rebut the last antecedent inference" and applicable where the "modifying clause appeared ... at the end of a single, integrated list." 131 That, notably, is a close description of Lord Bramwell's principle. ${ }^{132}$ Next, in Paroline v. United States, the Court invoked Porto Rico Railway to support reading the modifier "as a proximate result of the offense" as applicable to an entire set of antecedents. ${ }^{133}$ But Paroline was actually a case in the mold of Standard Brewery; the last antecedent was a catchall that referred broadly to "other losses suffered," which-like Standard Brewery's "other intoxicating" language-informed the earlier antecedents for semantic reasons, not structural ones. ${ }^{134}$ And in Lockhart $v$. United States, the Court summed this all up: The series-qualifier canon (at

\footnotetext{
126 Great W. Ry. Co., 9 App. Cas. at 808 (opinion of Bramwell); see supra notes 114-117 and accompanying paragraph.

127 Porto Rico Ry., 253 U.S. at 348 (emphasis added).

128 See supra notes 92-101 and accompanying text.

129 See Facebook, Inc. v. Duguid, 141 S. Ct. 1163,1169 (2021).

130 United States v. Bass, 404 U.S. 336, 339-40 (1971).

131 See Jama v. ICE, 543 U.S. 335, 344 n.4 (2005) (Scalia, J.) (first citing Bass, 404 U.S. at 337, 339, then citing United States v. Standard Brewery, Inc., 251 U.S. 210, 218 (1920), then citing United States v. United Verde Copper Co., 196 U.S. 207, 213 (1905)).

132 See supra note 117 and accompanying text.

133 Paroline v. United States, 572 U.S. 434, 447 (2014).

134 See id.
} 
the time referred to as a "principle") was not a "grammatical mandate" but a way to describe certain contexts that can rebut the last antecedent rule. ${ }^{135}$

Nevertheless, the Facebook majority - drawing on a single treatise and Porto Rico Railway and its progeny-cited the series-qualifier canon as a "traditional tool[] of statutory interpretation" built on "rules of grammar" that "generally reflects the most natural reading of a sentence." 136 Each of those descriptions is wrong. The Facebook majority's so-called seriesqualifier canon is not traditional; it differs markedly from the narrower principle that Lord Bramwell recognized and that the Supreme Court first applied in Standard Brewery. ${ }^{137}$ Indeed, the canon even differs materially from Porto Rico Railway, the case that first reformulated the underlying principle in a broader-and erroneous-way. ${ }^{138}$ Even Porto Rico Railway recognized that the principle applies only after a semantic match has been confirmed. ${ }^{139}$ Nor is the canon a rule of grammar. The canon does not describe how people generally use language, ${ }^{140}$ and it seems flatly at odds with research on how people process ambiguous structures ${ }^{141}$ - a fact that contradicts the claim that the "canon generally reflects the most natural reading of a sentence." 142 The so-called series-qualifier canon does nothing more than reformulate a misstated principle from a long-dated case.

\section{B. Facebook's Process Error}

This is not to say that a series-qualifier-like principle has no role in statutory interpretation. The principle confirms that where there is a semantic match between a broad postpositive modifier and multiple antecedents structured together, there is nothing unnatural about reading the modifier as applying to each antecedent. As discussed, Lord Bramwell's initial principle - even as applied in Porto Rico Railway — bakes in a threshold semantic determination. Before the series-qualifier principle applies, the interpreter must first determine that the modifier is "applicable" to each

135577 U.S. 347,355 (2016). In this connection, note that Lord Bramwell's principle-which applies where the modifier is broad - provides a natural complement to the last antecedent rule, which the Court has previously explained applies where the modifier is "limiting." Barnhart v. Thomas, 540 U.S. 20, 26 (2003) (Scalia, J.).

136 Facebook, Inc. v. Duguid, 141 S. Ct. 1163, 1169, 1170 n.5 (2021) (first citing SCALIA \& GARNER, supra note 13, at 147, then citing Paroline, 572 U.S. at 447, then citing Bass, 404 U.S. at 339-40).

137 See supra notes $97-117$ and accompanying text.

138 See supra notes 122-129 and accompanying text.

139 Compare Porto Rico Ry., Light \& Power Co. v. Mor, 253 U.S. 345, 348 (1920) (the rule applies where the modifier "is applicable as much to the first and other words as to the last"), with Facebook, $141 \mathrm{~S}$. Ct. at 1169 (no such limitation).

140 See supra notes 65-66 and accompanying text.

141 See supra note 60 and accompanying text.

142 Facebook, 141 S. Ct. at 1169. 
potentially relevant antecedent. ${ }^{143}$ After identifying a semantic match, the principle (as properly articulated by Lord Bramwell, not as inexplicably altered in Porto Rico Railway) confirms that application of the modifier to each semantically matching antecedent is syntactically permissible. ${ }^{144}$ The principle's narrow role is to say that a particular reading need not be ruled out as ungrammatical and, by extension, as unlikely to reflect ordinary public meaning. Given that narrow role, the Court was exactly right in Bass when it said the principle is "neither overwhelming nor decisive." 145

But the Facebook majority works backward. One of the contested issues in Facebook was whether there was a semantic match between the modifier and one potential antecedent. Recall that the relevant modifier is "using a random or sequential number generator," and the possible antecedents were two verbs relating to telephone numbers: "to store" (the further removed antecedent) and "produce" (the last antecedent). ${ }^{146}$ There is nothing semantically absurd about using a "number generator" to "produce telephone numbers." But it is less intuitive that a number generator would store those numbers. Ultimately, the Court rejected any semantic mismatch between "store" and "generator," but only by resorting to technical intricacies and policy concerns. ${ }^{147}$ Indeed, the majority conceded "that, as a matter of ordinary parlance, it is odd to say that a piece of equipment 'stores' numbers using a random number 'generator." 148 But the Court brushed that aside because it already stacked the deck: Having applied the series-qualifier canon as its first analytical move, ${ }^{149}$ the Court casts the semantic arguments as "contrary to the ordinary reading of the text." ${ }^{150}$ That is exactly backward-you need to establish a semantic match before the seriesqualifier principle ever comes into play. Only after making the semantic and

\footnotetext{
143 Great W. Ry. Co. v. Swindon \& Cheltenham Extension Ry. Co. [1884] 9 App. Cas. 787 (HL) 808 (appeal taken from Eng.) (opinion of Bramwell); Porto Rico Ry., 253 U.S. at 348.

144 See supra notes 114-117 and accompanying paragraph.

145 United States v. Bass, 404 U.S. 336, 340 (1971).

14647 U.S.C. $\S 227$ (a)(1). In circuit court decisions splitting over the issue that Facebook resolved, the courts arguably devoted more attention to this semantic issue than the Facebook majority did. See, e.g., Duran v. La Boom Disco, Inc., 955 F.3d 279, $284-85$ (2d Cir. 2020) (assessing semantic and structural points bearing on this problem); Allan v. Pa. Higher Educ. Assistance Agency, 968 F.3d 567, 572-73 (6th Cir. 2020) (considering ordinary usage and surplusage problems); Glasser v. Hilton Grand Vacations Co., 948 F.3d 1301, 1307 (11th Cir. 2020) (same). Of note, Justice (then-Judge) Barrett's opinion for the Seventh Circuit considered semantic issues without ever invoking the series-qualifier canon. See Gadelhak v. AT\&T Servs., Inc., 950 F.3d 458, 464-65, 466 (7th Cir. 2020) (Barrett, J.).

147 Facebook, 141 S. Ct. at 1172 (citing "patents for devices that used a random number generator to store numbers to be called later" and fear of "classifying almost all modern cell phones as autodialers").

148 Id. at $1171-72$.

149 See id. at 1169

${ }^{150} \mathrm{Id}$. at 1172
} 
syntactic determination is there arguably an "ordinary reading" established as a baseline. More simply, the majority put the cart before the horse.

This is the basic issue that Justice Alito identified. The central theme of Justice Alito's concurrence is that the common sense application of English semantics does most of the work. So, for example, in the sentence "[S]tudents must not complete or check any homework to be turned in for a grade, using online homework-help websites," Justice Alito argues that the series-qualifier canon does not resolve the reach of "using online homeworkhelp websites." 151 As he explains, our understanding "has little to do with syntax and everything to do with our common understanding that teachers do not want to prohibit students from doing homework." 152 Justice Alito worries that the majority's resolution of the question as a problem of syntax, rather than one of semantics and social context, will lead lower courts astray if they begin treating statutory interpretation as mechanical and algorithmic rather than contextual and informed by common sense drawn from social experience. ${ }^{153}$ With these observations, Justice Alito alludes to the methodological problem: The Facebook majority committed a process error. By that I mean that the Facebook majority took a syntactic principle designed to confirm the permissibility of a semantics-based interpretation and turned it into a principle that establishes the interpretation in the first instance. ${ }^{154}$

Why did this process error occur? The simplest answer is that the Facebook majority had no good reason to think it was making an error. By its terms, the so-called series-qualifier canon makes a broad claim about how English works, and it does so with Justice Scalia's leading textualist imprimatur. Those who have not done the legwork to critically assess the canon's grammatical or historical bases have no reason to suspect that the canon claims to resolve more than it can. On the surface, the canon's linguistic and historic pedigree looks as good as any other textualist's tool.

Perhaps, however, the Facebook majority used the canon so forcefully because it allowed the majority to write a quick and easy opinion. By the time Facebook reached the Court, much ink had been spilled across the circuits grappling with the interpretive issue. ${ }^{155}$ As then-Judge Barrett wrote for the Seventh Circuit, there are "at least four ways" of reading the statutory

\footnotetext{
${ }^{151} I d$. at 1174 (Alito, J., concurring).

$152 I d$.

153 See id. at $1174-75$.

154 To be clear, I take no position on the merits of the question presented in Facebook. My point is narrow: The Court's analysis is not methodologically sound. A mere process error, however, does not establish that the Court's ultimate answer on the merits is incorrect.

155 See cases cited supra note 146; see also Marks v. Crunch San Diego, LLC, 904 F.3d 1041, 105051 (9th Cir. 2018) (concluding "[a]fter struggling with the statutory language ... that it is not susceptible to a straightforward interpretation based on the plain language alone").
} 
text at issue in Facebook. ${ }^{156}$ Rather than get deep in the weeds of each-as Justice Barrett did for the Seventh Circuit ${ }^{157}$ — the majority may have thought that the series-qualifier canon is a relatively sound, rule-like way to quickly justify the answer that the full Court agreed was correct. If that is the explanation, then the Facebook majority's strategy has rhetorical appeal. An easy way to get around hard questions is to identify a rule that purports to cut through the arguments and supply a presumptive answer. By using the series-qualifier canon as it did, the Facebook majority could simply dismiss the serious semantic arguments about a mismatch between "store" and "generator" as good-but-not-good-enough. ${ }^{158}$

Regardless of explanation, textualists should not celebrate Facebook's approach. Rule-like formality in textualism may well produce benefits like the preservation of judicial legitimacy, ${ }^{159}$ but textualism's ultimate objective is to faithfully carry out the legislative directive as ordinary people would understand it. ${ }^{160}$ That the series-qualifier canon is rule-like is not a good in itself, nor is the fact that it is a rule that can make hard cases appear easy. Rules are valuable to the extent that they constrain interpretive discretion toward outcomes that accord with what ordinary people would understand words to mean, thereby furthering important democratic values.

If we take these values seriously, then we should heed Justice Alito's warning. In its original (and defensible) form, Lord Bramwell's seriesqualifier principle merely confirmed that certain structures are possible, but not necessarily ordinary in all circumstances (e.g., where the modifier is restrictive rather than broad and general). The contemporary so-called seriesqualifier canon claims to do much more but, if strictly applied, will not always live up to that promise-for example, in situations of potential semantic mismatch between a modifier and all items on an integrated list. Yes, there will be instances in which the canon yields the right result, but those instances will be happy accidents and not the product of settled, generally accepted linguistic conventions. If lower courts begin to use the canon as the Facebook majority did, the result may be to undermine rather than to advance textualism's commitment to identifying objectified intent.

\footnotetext{
156 Gadelhak v. AT\&T Servs., Inc., 950 F.3d 458, 463 (7th Cir. 2020) (Barrett, J.).

157 See id. at 463-64.

158 See Facebook, 141 S. Ct. at 1171-72 (describing the semantic case as "a valiant effort" to show that the majority's reading is "'linguistically impossible' or contextually implausible" (quoting Encino Motorcars, LLC v. Navarro, 138 S. Ct. 1134, 1141 (2018))).

159 See Grove, supra note 22, at 296-307.

160 See supra notes 25-28 and accompanying text; Barrett, supra note 2, at 112 ("Textualism... maintains that the statutory text is the only reliable indication of congressional intent.").
} 


\section{CONCLUSION}

The purpose of this Essay has been to shed light on the historical and theoretical bases for the contemporary so-called series-qualifier canon. I argue that both as a matter of sound linguistics and historical interpretative practice, the series-qualifier canon as articulated and applied by the majority in Facebook has no basis. That is not to say that the general principle is of no value. I acknowledge that a narrower version of a series-qualifier principle is a legitimate tool of interpretation. But like any tool, it can be misused. By using the so-called series-qualifier canon to establish a baseline interpretative outcome, the majority in Facebook misused the principle to prove a proposition that the principle was historically never intended to establish in the absence of a threshold semantic judgment. Recognizing that process error validates Justice Alito's concern that lower courts may be led astray by the Facebook majority's rush to use so-called rules when common sense does the job. But at a broader level, the Facebook error is a reminder not to let conventional or inherited wisdom about supposed linguistic conventions go unexplored or unchallenged. 